\title{
55. DATA REPORT: SOME PLANKTONIC FORAMINIFERAL DATUM LEVELS DURING THE LAST 10.4 MA, LEG $133^{1}$
}

\author{
Dick Kroon ${ }^{2}$
}

\section{INTRODUCTION}

This preliminary report does not present the distribution of selected key planktonic species in each Leg 133 hole, but rather, extracts the best chronodatum levels in two sets of holes, which comprise the Queensland Trough and Townsville Trough transects (Fig. 1). In general, the sampling interval was $1.5 \mathrm{~m}$, but sometimes was larger. To convert the datum levels into time, the absolute ages of Berggren et al. (1985) were used. Extinction levels were employed in the main, because they are the most easily recognized, the order of events seems to be consistent from hole to hole (Figs. 2 and 3), and they correlate reasonably well with chronodatum levels obtained from nannofossil biostratigraphy (see Gartner et al., this volume).

To place the datum levels into Blow's zonation scheme (1969), zonal boundaries have been indicated in one of the holes in each transect (Figs. 2 and 3). The N22/N23 lower zonal boundary, based on the first occurrence of Globorotalia truncatulinoides (d'Orbigny), is located well below the extinction levels of Globigerinoides fistulosus (Schubert) (1.6 Ma), and Globigerinoides obliquus Bolli (1.8 $\mathrm{Ma})$, which infers an older regional appearance age than that of 1.9 $\mathrm{Ma}$, suggested by Berggren et al. (1985). Therefore, this datum level was not used. A more detailed study will be needed to document the first appearance level of $G$. truncatulinoides in this area. Nor was an attempt made to locate all the Pleistocene datum levels, as given recently by Chaproniere (1991), because of publication deadlines. An age of about 3.0 Ma, the latest occurrences of Globoquadrina altispira (Cushman and Jarvis) and Sphaeroidinellopsis sp. were used, although other potential candidates include the extinction level of Globorotalia limbata (d'Orbigny) (including Globorotalia multicamerata Cushman and Jarvis, $2.9 \mathrm{Ma}$ ) and the first occurrences of Globorotalia tosaensis (Takayanagi and Saito) (3.1 Ma) and Globigerinoides fistulosus (2.9 Ma). However, the first occurrence of Glob. fistulosus is below the latest occurrence of Sphaeroidinellopsis sp. in most holes, which suggests that this biostratigraphic event is somewhat older in this area than the datum given by Berggren et al. (1985).

The extinction level of Globigerina nepenthes Todd (3.9 Ma) seems to be consistent from hole to hole, and thus has been included here. The latest occurrence of Globorotalia margaritae Bolli and Bermudez coincides more or less with the latest occurrence of $G$. nepenthes at about $3.9 \mathrm{Ma}$ in Hole $811 \mathrm{~A}$ and is a promising datum level.

Further, the first occurrence of Globorotalia tumida tumida (Brady) (5.2 Ma) appears to be consistent throughout the holes, although it is the only nonextinction event. The first occurrences of Pulleniatina primalis Banner and Blow and Neogloboquadrina humerosa (Takayanagi and Saito) were not included because identification is highly subjective and thus author-dependent. In addition, their first occurrences may vary between different areas because of prevailing environmental conditions.

The lowest chronohorizon recognized in some holes was the latest occurrence of Globorotalia siakensis LeRoy (10.4 Ma; Tables 1 and 2). The first occurrence of Neogloboquadrina acostaensis Blow (10.2 $\mathrm{Ma}$ ) was excluded because debate about this datum level is found in the literature. According to Barron et al. (1985), this species appeared at $8.6 \mathrm{Ma}$, but Berggren et al. (1985) assigned an age of 10.2 Ma. In addition, temperature may play a role in the development of this species, which might lead to diachroneity.

\section{ACKNOWLEDGMENTS}

D.K. was supported by NERC Grant No. GST/02/524. I thank Allan Melillo for his useful comments about the manuscript.

\section{REFERENCES ${ }^{*}$}

Barron, J.A., Keller, G., and Dunn, D.A., 1985. A multiple microfossil biochronology for the Miocene. In Kennett, J.P. (Ed.), The Miocene Ocean: Paleoceanography and Biogeography. Mem.-Geol. Soc. Am., 163:21-36.

Berggren, W.A., Kent, D.V., and Van Couvering, J.A., 1985. The Neogene: Part 2. Neogene geochronology and chronostratigraphy. In Snelling, N.J. (Ed.), The Chronology of the Geological Record. Geol. Soc. London Mem., 10:211-260.

Blow, W.H., 1969. Late middle Eocene to Recent planktonic foraminiferal biostratigraphy. In Brönniman, P., and Renz, H.H. (Eds.), Proc. First Int. Conf. Planktonic Microfossils, Geneva, 1967: Leiden(E.J. Brill), 1:199-422.

Chaproniere, G.C.H., 1991. Pleistocene to Holocene planktic foraminiferal biostratigraphy of the Coral Sea, offshore Queensland, Australia. BMR J. Aust. Geol. Geophys., 12:195-221.

\footnotetext{
Abbreviations for names of organizations and publication titles in ODP reference lists follow the style given in Chemical Abstracts Service Source Index (published by American Chemical Society).
}

Date of initial receipt: 24 April 1992

Date of acceptance: 19 January 1993

Ms 133SR-276

\footnotetext{
${ }^{\prime}$ McKenzie, J.A., Davies, P.A., Palmer-Julson, A., et al., 1993. Proc. ODP, Sci. Results, 133: College Station, TX (Ocean Drilling Program).

${ }^{2}$ Department of Geology and Geophysics, University of Edinburgh, West Mains Road, Edinburgh EH9 3JW, Scotland.
} 


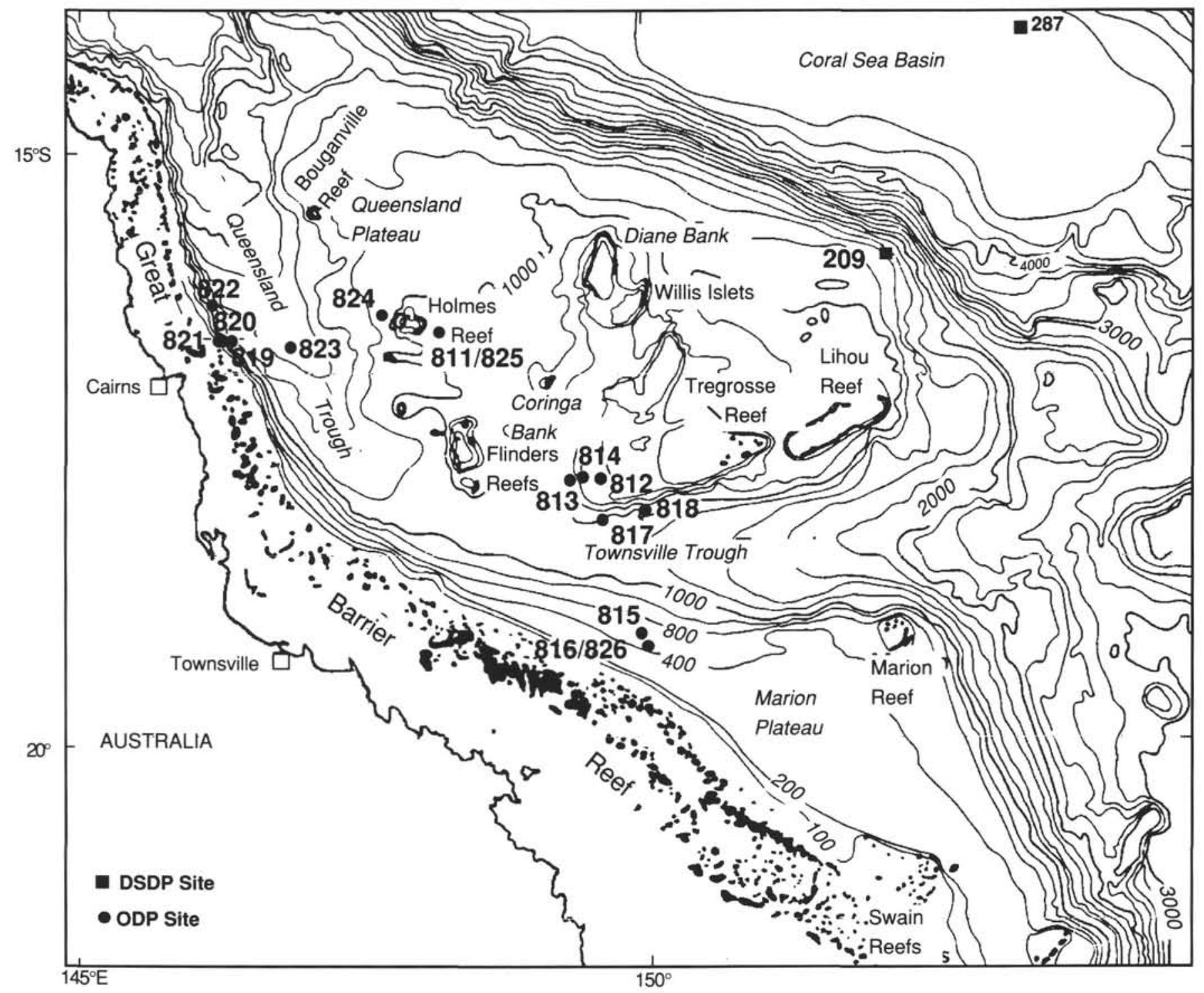

Figure 1. Locations of Leg 133 sites. 


\section{QUEENSLAND TROUGH TRANSECT}

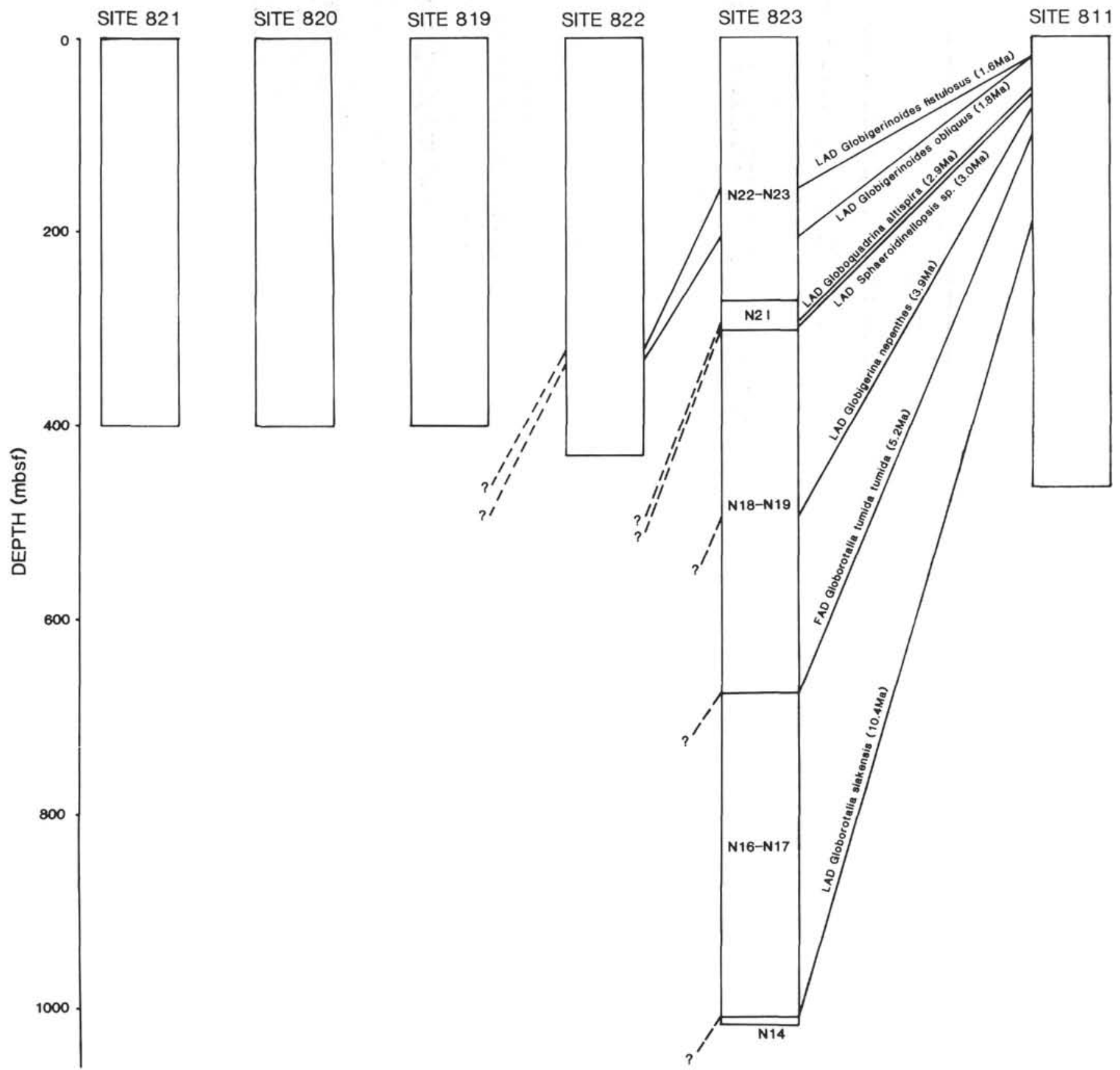

Figure 2. Correlation of Queensland Trough sites on the basis of observed planktonic foraminiferal datum levels. 


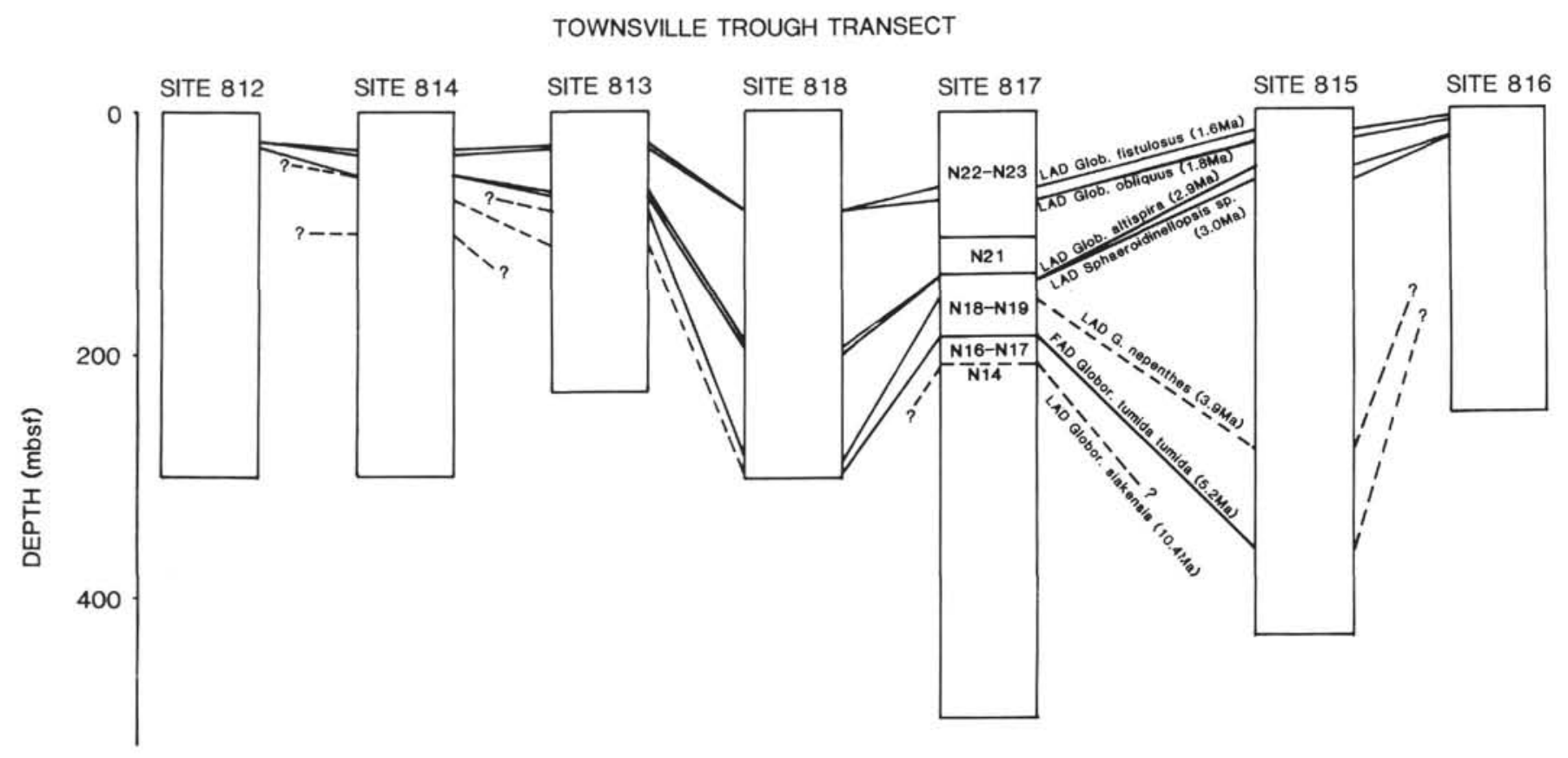

Figure 3. Correlation of Townsville Trough sites on the basis of observed planktonic foraminiferal datum levels.

Table 1. Data for depth intervals of planktonic foraminiferal datum levels (Queensland Trough transect).

\begin{tabular}{lccc}
\hline \multicolumn{1}{c}{ Species } & Site & $\begin{array}{c}\text { Age } \\
\text { (Ma) }\end{array}$ & $\begin{array}{c}\text { Depth } \\
\text { (mbsf) }\end{array}$ \\
\hline LAD Glob. fistulosus & 822 & 1.6 & $317.5-327$ \\
& 823 & 1.6 & $151.4-154.9$ \\
& 811 & 1.6 & $17.4-24.5$ \\
LAD Glob. obliquus & 822 & 1.8 & $327-336.6$ \\
& 823 & 1.8 & $199.8-209.1$ \\
LAD Globoq. altispira & 811 & 1.8 & $17.4-24.5$ \\
LAD Sphaeroidinellopsis sp. & 823 & 2.9 & $88.7-291.7$ \\
LAD G. nepenthes & 811 & 2.9 & $50.4-53$ \\
FAD Globor. tumida tumida & 811 & 3.0 & $295.6-299.3$ \\
& 811 & 3.9 & 487.59 .3 \\
LAD Globor. siakensis & 823 & 5.9 & $72-491.2$ \\
& 811 & 5.2 & $673.8-676.6$ \\
& 811 & 10.4 & $1005-102.9$ \\
& 10.4 & $188.4-19011$ \\
& & & \\
\hline
\end{tabular}

$\mathrm{LAD}=$ Last appearance datum level; FAD $=$ First appearance datum level.
Table 2. Data for depth intervals of planktonic foraminiferal datum levels (Townsville Trough transect).

\begin{tabular}{|c|c|c|c|}
\hline Species & Site & $\begin{array}{l}\text { Age } \\
\text { (Ma) }\end{array}$ & Depth (mbsf) \\
\hline \multirow[t]{7}{*}{ LAD Glob. fistulosus } & 812 & 1.6 & $23.9-24.5$ \\
\hline & 814 & 1.6 & $27-31.5$ \\
\hline & 813 & 1.6 & $24.7-26.8$ \\
\hline & 818 & 1.6 & $81.6-84.4$ \\
\hline & 817 & 1.6 & $62.7-64.8$ \\
\hline & 815 & 1.6 & $16.3-18.5$ \\
\hline & 816 & 1.6 & $5.5-7.6$ \\
\hline \multirow[t]{7}{*}{ LAD Glob. obliquus } & 812 & 1.8 & $24.5-27.9$ \\
\hline & 814 & 1.8 & $31.5-34.4$ \\
\hline & 813 & 1.8 & $26.8-31.3$ \\
\hline & 818 & 1.8 & $81.6-84.4$ \\
\hline & 817 & 1.8 & $72.2-74.3$ \\
\hline & 815 & 1.8 & $23-25.8$ \\
\hline & 816 & 1.8 & $7.6-12.1$ \\
\hline \multirow[t]{7}{*}{ LAD Globoq. altispira } & 812 & 2.9 & $29.5-31.6$ \\
\hline & 814 & 29 & $50.5-53.4$ \\
\hline & 813 & 2.9 & $62.7-64.8$ \\
\hline & 818 & 2.9 & $191-195$ \\
\hline & 817 & 2.9 & $135.8-138.7$ \\
\hline & 815 & 2.9 & $44.8-47$ \\
\hline & 816 & 2.9 & $21.6-24.5$ \\
\hline \multirow{6}{*}{ LAD Sphaeroidinellopsis sp. } & 814 & 3.0 & $50.5-53.4$ \\
\hline & 813 & 3.0 & $64.8-69.3$ \\
\hline & 818 & 3.0 & $195-198.4$ \\
\hline & 817 & 3.0 & $135.8-138.7$ \\
\hline & 815 & 3.0 & $54.3-63.8$ \\
\hline & 816 & 3.0 & $21.6-24.5$ \\
\hline \multirow{5}{*}{ LAD G. nepenthes } & 814 & 3.9 & $66.5-76(?)$ \\
\hline & 813 & 3.9 & $78.8-81.7$ \\
\hline & 818 & 3.9 & $283.9-293.4$ \\
\hline & 817 & 3.9 & $151.8-156.3$ \\
\hline & 815 & 3.9 & $309.6-319.3$ \\
\hline \multirow[t]{5}{*}{ FAD Globor.tumida tumida } & 814 & 5.2 & $56.8-76(?)$ \\
\hline & 813 & 5.2 & $107.3-110.2$ \\
\hline & 818 & 5.2 & $293.4-302.9$ \\
\hline & 817 & 5.2 & $183.3-186.2$ \\
\hline & 815 & 5.2 & $358.1-367.8$ \\
\hline LAD Globor. siakensis & 817 & 10.4 & $205.2-207.2(?)$ \\
\hline
\end{tabular}

$\mathrm{LAD}=$ Last appearance datum level $; \mathrm{FAD}=$ First appearance datum level. 